\title{
Clothing Matters:
}

Asian-African Businessmen in European Suits 1880-1980

\author{
Gijsbert Oonk \\ Department of History (L3-75) \\ P.O. Box 1738 \\ 3000 DR Rotterdam \\ Netherlands \\ Oonk@eshcc.nl
}

\section{Summary}

Asian businessmen in East Africa supplied goods, services and capital to African, Arabic, Asian and European customers, traders and other businessmen. In this complex cultural environment, they had to choose what to wear on any given what occasion. Expressing dignity, wealth, trust and reliability are key variables in making cross-cultural business contacts and building an appropriate image. When they arrived in East Africa between 1880 and 1920, Hindus and Muslims alike wore their own traditional attire, headwear and footwear, or no shoes at all. When they left Africa - around 1970- they wore a typical European business suit, including a tie and shined black shoes.

In this article I explain the changing dress habits of Asian businessmen in East Africa as a result of -among others- 
the change in political environment from European colonies to African states, and the shift in economic preferences from dealing with India to dealing with Europe. Nevertheless, these factors should not be seen as a social economic structure imposed from above.

This article shows that adopting a European dress style was a way to demonstrate an ability to modernise, move with the times. In the context of Asians in East Africa, it should be emphasised that European clothes are an indication of their 'progressive' ideas, but must also be seen as a critique of their own culture.

Biographical statement:

Gijsbert Oonk is Associate Professor of Non-Western Societies at the Erasmus University Rotterdam, Netherlands. He works on the history of South Asian migrants in East Africa. He has published on Asian diasporas, Asian entrepreneurship and networks and the changing culture of Asians in Africa. He recently edited Global Indian Diasporas. Exploring Trajectories of Migration and Theory (Amsterdam University Press 2007) and G.Oonk, The Karimjee Jivanjee Family. Merchant Princes of East Africa (Pallas publications 2009). His work can be found at: www.asiansinafrica.com 
There is a striking contrast between today's study of dress and dress habits and that of a century ago. Contemporary research focuses on varying dress habits depending on gender, class, status and cultural background. In addition, we are aware that we dress differently for different occasions and environments, such as weddings, workplaces, schools, public and private spheres of interaction and so on. Moreover, the way we dress changes through generations and varies according to time and place. ${ }^{1}$

However, if we read travelogues of Western traders, diplomats, missionaries and early anthropologists from the nineteenth and early twentieth centuries, the picture differs remarkably. As described in these texts, it seems that each tribe, caste or ethnic group wears its own static and unchanging ethnic dress, which is said to be characteristic of that group. These publications were often meant to introduce the public in Europe about the 'strangeness' of overseas peoples. The most remarkable distinction made was the difference between 'nude tribes' and 'dressed cultures'. These observations became part of an evolutionary anthropology in

\footnotetext{
1 Regarding dress habits in India, Emma Tarlo has set an excellent standard with Clothing Matters. Dress and Identity in India (Tarlo 1996). Note that I have taken the first part of the title from this book.
} 
which other civilisations were seen as stages of development moving towards modern Western civilisation, the ultimate aim of evolutionary progress. ${ }^{2}$

This perception changed in the $1950 \mathrm{~s}$ and $1960 \mathrm{~s}$ when anthropologists like Louis Dummont (1970)started to write about culture in terms of an interrelation between functions and social institutions. This functionalist school of anthropology dispelled the Western myths of exoticism and strangeness of the 'other'. It was shown that kinship systems, lifestyles and rituals were a function of rational, internal system. One of the aims was to show that Western civilisation was not the necessary outcome of cultural stages of development and that each culture had its own rationality. Dumont's focus was on the rationale of the caste system. However, in the evolutionary as well as the functionalist

2 Early anthropologists would focus on religion and kinship rather than dress. Lewis Henry Morgan, for example, was a proponent of social evolution. He proposed a unilinear scheme of evolution from primitive to modern, through which he believed societies progressed. His evolutionary views of the three major stages of social evolution -savagery, barbarism, and civilization- were proposed in Lewis Henry Morgan, Ancient Society, London 1877. Every good introduction in the field of anthropology includes a section on this area. I base my comments here on Alan Barnard (2000). 
approach, the 'other' was described in isolation and passivity, not in interaction and dynamic change.

The current emphasis has changed again, from the notion of a 'static other' to the awareness that people migrate, trade and interact with each other. Their culture changes in the process. However, the question remains: how and why does culture change and in what direction? These questions refer to a long debate in historical anthropology regarding such concepts as acculturation, assimilation, integration, syncretism and diffusion. ${ }^{3}$ More recently, these concepts had been overshadowed with notions of subordination, in general a top-down process from the subordinated non-Western culture towards a more Westernised culture. ${ }^{4}$ Finally, the debate on

3 Redfield, Linton and Herskovits (1936) and Herkovits (1938) distinguish three types of results of acculturation: (1) acceptance, i.e. adoption of a large part of the other culture without protest or adaptation; (2) adaptation, creating a combination of indigenous cultural elements and some cultural elements from the 'other' culture, and (3) reaction, i.e reaccentuation of the indigenous culture as a reaction to cultural interaction (Herkovits 1938: 135-138).

4 "Acculturation: Culture change due to contact between societies; most often used to refer to adaptation of subordinate tribal societies to domination by Western societies." (Keesing 1976: 507). 
globalisation seems to praise the post-modern global

interaction process in which cultures "are more globalized, cosmopolitan and creolised or hybrid than ever". (S. Vertovec, in Cohen 1997: 128. Also U. Hannerz (1996)). Nevertheless, while processes of cultural combination, also known as creolisation, may take place within a global continuum of relations (Drummond: 1980, Hannerz: 1996), they nonetheless attain their significance in concrete contexts of interpersonal relations (Oonk: 2004a).

Social status and prestige play an important role in interpersonal relations. It is interesting to note that the theories of cultural anthropology discussed above evolutionary, functionalist and interaction-based - serve as good reference points for studying dress habits as a tool for elite status. In most situations, going naked is considered to be inappropriate and 'low status', denoting savagery. Traditional ethnic attire is appreciated at many occasions, but still considered 'simple'. The dress code of elite politicians and businessmen, however, consisting of the typical Western business suit with tie and shiny shoes, is considered 'modern'. In fact, it has become the international uniform of business and politics. Of course, the quality, brand name and colour may differ, but in general the suit looks surprisingly similar in Europe, South Asia, the Americas and Africa. 
In this article, I describe how and why the Western business suit became acceptable among South Asians in East Africa. This is an interesting case because it is the outcome of the interaction between Swahili traders, South Asian (Hindus and Muslims) merchants, Arabic dealers and planters and European businessmen and colonial officials in East Africa. The political economy of Zanzibar and the East African Coast in the $19^{\text {th }}$ century is often described as a pyramid comprising Arab and European rulers and businessmen, South Asians and Swahilis. At the top were the Western firms, rational, highly capitalised and often organised on the jointstock principle. The Arabs owned plantations and produced cloves and spices. Some were involved in the caravan trade to collect ivory from the mainland. In many cases, the activities of the Arabs were financed by Indian moneylenders who did not own land or went into the interior themselves in the early nineteenth century. In the middle were the South Asian family firms who acted as intermediates. At the bottom were the Swahilis, who were often described as ignorant, living one day at a time and in the end incapable of rational economic behaviour in terms of investment and reinvestment in profitable businesses. The reality, however, was more complex than this simple pyramid model, especially in relation to South Asians, who were found at both the top and bottom of the society (Clarence-Smith 2001: 335-349). 
These business groups interacted with each other freely, trading and dealing without restrictions. At the same time, however, they lived in different quarters in the small cities and towns. Often there was a Hindu quarter, an Arabic quarter, a Native area and a European area. These groups hardly intermarried at all and, with only a few exceptions, did not build surviving business partnerships. And last but not least, they all wore different dresses and outfits while doing business. In other words, this was a highly segregated society. How, then, is it that those who became successful businessmen ended up in the same 'European' business suit? This development is all the more surprising because one would expect that those who could afford it would find it easier to remain within the limits of their own dress code than those who were not flourishing

The article is divided into four sections. After this introduction, I describe the segregated society of Zanzibar and the East Coast of Africa. In the second section, I emphasize the way South Asian businessmen are described by Western observers for the period roughly from 1880-1920. In the third section, I show how South Asians businessmen dressed differently for different occasions. The Western business suit became acceptable, but was still not pre-dominant among Asians in East Africa between 1920 and 1960. After the 1960s, many had accepted the European business suit as part of their daily wear, having already decided to become 'transnational'. 
However, this was not solely a reaction to the local political arena. It was part of global changes in the South Asian diaspora as well, as we will see. In the fourth section, I will conclude that the acceptance of the Western business suit was the result of clever navigation on the part of the south Asian businessmen between local changes, the establishment of colonial and Asian schools and education projects. In addition, I argue that it is a reaction to the Africanisation projects as well as the adaptation towards a more global business environment.

This article is based on my archival and a year's fieldwork and archival research conducted in East Africa in 2002-2003, and shorter visits hereafter. It also develops on extensive stays in the British Library and the colonial archives in Kew. It is based on written sources, images and paintings as well as oral history. ${ }^{5}$ I interviewed more than 200

5 The research was made possible by the Netherlands Foundation for the Advancement of Tropical Research (WOTRO) in collaboration with the History Department of Erasmus University Rotterdam, Netherlands. The research is based on archival as well oral history conducted in de period between 1999-2003, including a year of fieldwork between July 2002 and July 2003. I visited the Tanzania National Archives (hereafter TNA) and the Zanzibar Archives (hereafter ZA) extensively. In addition, several references are made to the Kenyan National 
people from different communities, equally divided between Hindus and Muslims. The majority of interviews were conducted in Dar es Salaam and a few in Nairobi, Arusha and Mombasa. My main focus was on South Asian families that had settled in East Africa between 1880-1920. By the time they left East Africa they had developed as third generation migrants. In this article the main focus is on the male members and their dress habits.

The way we dress is but one way to express our identity and prestige. For historians, however, it is an excellent resource, because pictures, images and paintings may serve as our primary sources. During my fieldwork, I often asked to see the photo albums of the family; some of them allowed me to make scans. The interviews conducted while looking at family pictures revealed excellent information about dress habits on different occasions, as I will show.

\section{Static Segregation or Dynamic Change?}

archives (KNA) and the Public Record office (PRO) in London, where I saw documents from the Colonial Office (CO) and the Foreign Office (FO). There are many Asian-African business families which I have visited regularly since 2003. Some of them have become close friends. I have published earlier about methods and fieldwork. See Oonk 2004; 2006; and 2007. 
Most late nineteenth-century writings on 'peoples and customs' in East Africa depict a highly segregated society. The different religions, marriage patterns, food and dress habits are often presented in static segregated order. There seems to be no room for interaction between groups, or for change. This is confirmed with early plans of cities in East Africa. If one looks at old geographical maps of Zanzibar, Nairobi, Dar es Salaam and other places in East Africa, there is always a Hindu quarter, a Khoja quarter and a Bohra quarter in town. These quarters where not necessarily imposed by colonial politics, but may well have been self-imposed to avoid cultural interaction as much as possible.

This is confirmed by the nineteenth century British traveller Palgrave, who observed that Hindus are even stricter than other Asians in Africa. Because of their strict caste rules and notions of cleanliness, Hindus seem to remain in close proximity, more so than other Indian, Arab and Swahili communities. He referred to them as "interfering with no one, seeking nothing beyond their direct line of business". (Palgrave: 1865: 369-370)

The British medical doctor James Christie visited Zanzibar regularly between 1821 and 1872 . He was especially interested 
in the causes and consequences of the cholera epidemics in the area. He writes in 1876 about the Bohras in Zanzibar. ${ }^{6}$

They are less numerous than the Khojas, and are similarly occupied in commerce (...). The Bahoras [sic] are a highly respectable class of people, and quietly pursue their own avocations without interfering with anyone else. They are rigid Moslems, but worship in their own mosque, and have no connections with other Mohammedan sects. They have their peculiar dress, and are the only class in Zanzibar, with the exception of the Persians, who wear a kind of trousers. (Cristie: 1876: 466)

In other words, even within the South Asian Muslim community, interaction between sub-communities was hardly observed. This is not to say that these interactions did not exist, but they were hardly seen nor mentioned by outsiders. In fact, trading is about interaction. Traders deal constantly with 'outsiders' as they visit the shop and introduce themselves as customers. In the case of retailers, they visit suppliers or traders who do not necessarily share the same

\footnotetext{
6 The Bohra community accounted for less than 600-800 people around the 1860s. Contrary to Hindus, they tended to settle with their families and not as single males. For a summary of migration histories of Asians in East Africa (Oonk: 2004a: 723) .
} 
religion or ethnic, caste or class background. In fact, traders create a culture of interaction where differences are accepted. Often, the informal exchanges start with who you are, what your (religious) background is, and other interactions.

The different ways businessmen dress often convey more than one message of identity. Each group seem to wear their peculiar dress', which therefore tends to emphasise difference rather than commonality. The famous British explorer Richard Burton (Burton: 1872: 331), for example, often included in his books chapters like 'Ethnology of Zanzibar', 'the Arabs' or 'the Hindoos' (sic). About the dress of 'Indian Bhatias' in Zanzibar he writes: "His large-peaked Cutch turban, white cotton coat or shoulder cloth, and showery Indian dhoti around the lions, contrasts favourably with the Arabs' unclean garb." In general, travellers compared the attire of specific ethnic or religious groups. Special attention was attributed to the dress of the (religious) ruler, the King, the sultan or the Maharajah, but this was seen as an exception.

The British traveller Pearce (1920: 254) writes about the Ithnasheries in Zanzibar in the 1910:

"The dress affected by the young Indians in Zanzibar is distinctly ugly, and comprises a small black 'polo cap' as head covering, a white or black cotton jack cover reaching to below the knees, similar in shape to the now prehistoric European frock-coat, and a pair of rather 
tight white trousers. (...) Except for the hair-covering, which takes the form of a made-up turban cap of gold brocade, the everyday costume of the Khoja men is not very distinctive."

Differences within or between groups were hardly observed and not systematically studied. Occasionally, some difference between men's and women's dress were noticed.

There is one interesting, but exceptional, example written in 1920, which refers to different types of dress for different occasions (Pearce: 1920: 254). It mentions that at functions the head of the community would dress in full regalia to show off his importance. In addition, it shows some rare evidence of change or interaction with European dress styles, as the garments were cut along European lines. Except for the hair-covering, which take the form of a made-up turban cap of gold brocade, the every day costume of the Khoja men is not very distinctive. It consists of a coat and trousers and white cotton material, the garments being cut on European lines. At a function, however, the heads of the community blossom forth into a handsome kind of uniform, consisting of a richly embroidered cloth of gold turban and a robe composed of a very beautiful 
material of Persian manufacture, heavily embellished with gold lace. ${ }^{7}$

To a certain extent this reflects something we all know, but tend to forget. The way we dress encapsulates various messages. First, it is a message to the family and close community. One dresses according to the customs of the direct environment, or chooses not to. However, the same message is also sent to outsiders. It therefore also shows outsiders the extent to which one tends to conform to the close-knit community and the extent to which one tries to rebel and be 'different'. The acceptance of Western dress in these communities sends the message of admiration and adaptation, but it also may be seen as protesting against the manners and etiquette of the elite of one's own society.

7 On the same page ((Pearce: 1920: 254): "The attire of the Bhoras is pain and unassuming, consisting of a long white cat and losse white cotton trousers. The usual head-dress is a small round cap, but the more affluent members of the community wear a cloth-of-gold turban cap, somewhat similar to that worn by the Khojas." 


\section{Changing Cultures}

Despite the static and unchanging image of dress habits in the previous section, we are aware that people interact, change and develop. In fact, cultures are not preserved by protecting them from mixing with other cultures, but can probably only continue to exist as a product of such intermingling. The question is how and in what direction this is happening. It may not come as a surprise that areas of cultural interaction, such as business dealings, are important venues where change occurs. Education and schooling also represents an important area of interaction.

Karimjee brothers in 1924. Reprinted from Oonk 2009: 47.

There is a famous picture of three of the Karimjee businessmen in front of a huge Swahili-style door in Zanzibar. The picture is taken after finalising the agency agreement with Caltex for the distribution of oil products in East Africa in 1924. On the right we see Tayebali Karimjee (18971987), who would become the master of charities in the Karimjee family. On the left we see Yusufali Karimjee (1882- 
1966) who was the born trader and 'outward bound' manager of the Karimjee businesses. He travelled from Zanzibar to Japan and from South Africa to the UK to inspect trades, quality of products and prices personally. In the middle we see Mohamedali Karimjee (1875-1940), who was the second eldest son of Alibhai Karimjee Jivanjee (1851-1883). At the time the picture was taken, Mohamedali was the family eldest and head of the family. He managed the business affairs from the head office in Zanzibar.

It is not surprising that the outbound (export) manager was dressed in a suit and tie. He was the one who dealt with Europeans and he changed his dress accordingly. However, at the same time, he is wearing a turban, which clearly shows that he is not European. In fact, this type of turban was very specific to the Bohra communty in East Africa. In other words, it was part of their 'peculiar dress' as mentioned by Pearce in the last paragraph. This is not to say that he would dress in suit and tie on all occasions on which he dealt with Europeans. On the contrary, in 1910 he was invited to a lunch in London in honour of Alibhai Mulla Jeevanjee (not family). At that time, Jeevanjee was promoting 'equal rights' for Asians in East Africa in the heart of the empire. He was talking to representatives of parliament and other public figures. At the lunch, like any other Asian-African, he wore his Asian dress, including a turban. About half of the group 
were Europeans, who all wore European suits and ties (Oonk: 2009: 130).

In economic as well political affairs, there would seem to be some evidence which shows that the way groups dress was used 'instrumentally'. This may not come as a surprise, but it is interesting to note that simple day-to-day explanations such as people tending to dress towards the economic and political elite to create more dignity and prestige and so on is doubtful. Different perspectives on the same occasions play an important role.

First, the Karimjees themselves revealed that it would have been unthinkable to dress up like Europeans during the Jivanjee Lunch. Their grandfathers left as local heroes, dressed up as Bohra princes, to visit London. They were given a farewell party before they left from Zanzibar. ${ }^{8}$ Here as well, they would dress up like Bohra princes. They considered themselves to be the local, Zanzibari Asian-African elite. They went to London to support Jivanjee's claim for equal rights. They felt morally advanced. In their view, the British spoke about equality but were seen as untrustworthy. The Bohras in general saw themselves as the living examples of equality. Not only because of their Muslim faith, which was

\footnotetext{
8 The farewell party was given because of the travel abroad, not because of going to London. When the Karimjees went to India or Karachi, farewell parties were organised as well.
} 
important as well; the ultimate evidence was that they sponsored local schools and health institutions for all. In contrast, the colonial officials and missionaries were only interested in Africans, but not in Asians and Arabs. ${ }^{9}$ Some close friends of the Karimjees once explained to me that the Karimjees in East Africa had invented socialism, referring to their amount of charities on the island and East Africa. The British, in their view, were only interested in patronising the Asians in East Africa and securing their own interests. ${ }^{10}$ From this perspective there was no need to adapt to a European standard; it was morally and political self-evident to show your own dignity and differentness.

Second, the situation as it related to business dealings was different. Yusufali Karimjee was not seen as 'modern' for

9 This is the way they experienced the 'truth'. In fact, most of the schools they sponsored were community-based, but not all. (Oonk: 2007: 31-67)

10 Various interviews with three grandsons of the Karimjees. Interviews taken in April 2006 in London and August 2006 in Dar es Salaam. I met various members of the family several times since 2005. I have become close friends with them. Whenever I visit London or Tanzania I make sure to pay a visit. I was invited to their annual family lunch in London in October 2006 and November 2009. The total amount of charities was estimated at more than Euro 4,7 million (Oonk: 2009:133) 
his Western outlook. He was seen as a rebel in the family. He had travelled the world and adapted to all kind of circumstances. The examples presented here focus on his relationship with Europeans and European culture. His temporary and occasional adjustment should not be seen as an indication of his progressive ideas. It just showed that he could be part of different cultures, including the dominant British one. At the same time, however, the Bohras were demanding greater political freedom from the British.

There is an interesting picture of him, however, in his garden in Mombasa. Yusufali was born in Zanzibar like his parents and grandparents. However, many contemporaries as well as current researchers would see him as a South Asian in East Africa, not as an African. Others may define him as a Muslim, or more specifically a Bohra. Nevertheless, in the picture he wears a Japanese kimono. It appears that he is married to a Japanese woman, but he doesn't speak the language. His first language is Gujarati, but he is also fluent in English (reading, writing and speaking). In other words, it is very difficult to define his identity, or multiple identities. The example of Yusufali Karimjee is exceptional; nevertheless, it raises questions about the categorisation of identities and the classification of cultural change.

Third, it is fascinating to see that the Asian traders and businessmen in East Africa are often seen as 'middlemen minorities', acting as petty traders between the 
Europeans and Swahili producers. Nevertheless, the elite businessmen in East Africa often explained to me that this was not the case. They meant that for them the Europeans (!) were the middlemen between East Africa and the European markets. This also shows the strong sense of self-awareness of this emerging Asian-African elite. They did not relate themselves to Europeans; rather, they developed their own world, in which they used the Europeans to build their own commercial empire and create political room to raise their families. In other words, the partial adaptation to British society expressed in their dress habits was used for practical reasons.

This all may be true for the absolute elite of Asian African in East Africa. However, it does not explain why the majority of the upper middleclass of Asian-African businessmen shifted towards a Western-style business suit. I was struck by this fact when I was given two pictures taken only thirty years after each other. In the first picture, taken in 1954, all the community members wore their own traditional dress of that time, whereas only thirty years later, they all wore European business suits on the same sort of occasion.

In 1954, the Khoja Shia Ithnasheri community organised its first East African community conference in Mombasa. The picture shows the important organizers and members of the community at that time. All the members are male. Most of the persons portrayed wear the typical Muslim shirwanis with long coats and black caps. This was, at that time, the most common 
attire amongst the male members of the Khoja Shia Ithnasheri community. In addition, two interesting extremes occur in the image. On the one hand, we see that the most important person in the middle of the picture is wearing a turban, reflecting his importance and his ties to tradition. On the other hand, we see that he and a number of other members were wearing a tie, a direct adaptation of an important part of the European business suit. In this picture, one person (on the far right) is wearing a Western-style business suit, including a tie.

Ithnasheri community in Mombasa 1954

Ithnasheri community in Mombasa 1984

Only thirty years later, the Khoja Ismaili Ithnasheri community organised another gathering at the same place in Mombasa. The group portrait shows a striking contrast with the 1954 event. The turban, the black caps and the shirwanis or long coats have disappeared from the image. All members are wearing a European-style business suit with tie. This change was part of a longer process of adaptation, conformance and 
assimilation of dress habits among Asians in East Africa. How, then, should this be explained?

In my view, three areas of interest were important for the change in dress habits: (1) the emergence of a subsidised Asian-African educational institution in which school uniforms were compulsory; (2) the decline of the importance of trade with South and East Asia in favour of Europe; and (3) the role of religious leaders and institutions in guiding cultural processes of change.

(1) An elite is an interest group, and its cultures develop as a means of coordinating its corporate activities to enhance and maintain power. This is a complex phenomenon for the Asians in East Africa. In the colonial era, they relied heavily on the white colonial powers, which relied on them in turn. However, this did not preclude self-reliance. Elsewhere I have written more extensively about the emergence of Asian education in East Africa (Oonk: 2007: 31-67). The Christian missionaries in East Africa had little interest in South Asians. Nevertheless, the Asians could not afford to remain uneducated. They were professional traders, financers and brokers in East Africa. They had to deal with Europeans, Arabs and Africans, which required at least some education. They therefore took a great interest in educating their children and started their own schools from the moment Gujaratis 
settled in East Africa. ${ }^{11}$ During the colonial period, most South Asians in East Africa went to Indian schools where they were taught to read and write their 'own' languages. Though many schools were intended for certain communities or founded by religious institutions, others served a wide range of students of various backgrounds. ${ }^{12}$ Most of my respondents remembered that they had attended 'Indian schools' where Hindus and Muslims sat together. The prosperous South Asian business communities (partly) financed many of these schools. Most of the schools in East Africa were built along British models and rules, some of which the Asians remembered from colonial India. All the teachers were imported from India. However, surprisingly, many of them would wear 'British

11 See, for example, Director of Education to Honourable Chief Secretary, $16^{\text {th }}$ March 1925, Tanzanian National Archives (hereafter TNA), AB 1032, p. 4: "Throughout the Territory, wherever there is an Indian community of any size, Indian parents have taken steps to provide that their children shall, at least, be taught to read and write in Gujarati, and at big centres like Dar es Salaam, Tanga and Tabora and elsewhere English is also taught, and girls as well as boys rightly, attend these schools..." "'

12 The Ismailis, in particular the followers of the Aga Khan, were quick to build their communal-based Ismaili schools, which were nevertheless also accessible to other Indians. 
clothes'. This had become part of the educational institutions in many colleges in India. These teachers may therefore have set an example for the emerging Asian-African business community. The change of dress and dress types became acceptable. It is important to note here that school uniforms were compulsory and it was often the first time that children would wear clothes (and shoes!), which were more part of a British culture than their own.

In addition, over the course of time, the Asians in Africa lost their ability to read, write and speak the Gujarati language. Initially, the Asians had promoted their own languages in the educational institutions, but over time the colonial officials started to sponsor Indian education under the condition that the language of instruction would be English from the 'standard age' of four onwards. Moreover, on the eve of independence, the local governments started to promote Swahili as the language of instruction. At that time, the majority of the Asians in East Africa, at least those who could afford it, opted for 'English medium schools'. In other words, the change in educational systems made it slowly acceptable to wear Western attire and to speak and write English, not only on the playground, but gradually at home as well (Oonk: 2007: 31-67).

At the same time, a growing number of children went to colleges in Britain. The offspring of elite businessmen were sent to private schools in the UK, where they were exposed not 
only to the British children, their dress and language but also to different dietary customs, manners of introduction and ways of addressing each other, such as looking each other in the eyes if you say you speak the truth, instead of looking down out of respect for authority.

Others were sent to private schools and universities in India. However, this was not a historic rendezvous with the 'original culture'. On the contrary, these were colonial institutions, which were partly meant to prepare the pupils for further studies abroad. Again, it meant continuous exposure to British dress habits (school uniforms, formal dress for Christmas parties, etc.) and British history, language and so on.

(2) Over time, South Asian settlers in East Africa developed a gradual economic and social separation from India. This was a consequence of the severance of social ties evidenced by the growing preference for marrying Indian women raised in East Africa and, in the words and memory of the informants, the deterioration of economic relations (Oonk: 2004b: 70-88). Another reason was the growing importance of formal banking, which meant there was less need to re-enforce informal (family) banking networks. The importance of the 'Hundi system' (an informally organised credit system) declined in favour of formal banks. In other words, those family members who stayed in India and did not move to East-Africa grew less and less important as economic and social capital. 
Nevertheless, statistics reveal no dramatic decline in the figures for imports and exports from and to India. But, more importantly, the UK became the most important export destination. ${ }^{13}$ In the perceptions of Asian Africans, however, India was on the decline and the future was in Europe.

The economic and social separation from India was also reflected in the way the Indian National Congress tried to build the Indian Nation. One of the key issues was that they started to promote Indian-made clothes, especially khadi. This was the fine and simple way of dressing of the Indian peasants first adopted by Gandhi and in the early 1930s by almost all leaders of the Congress Party. Its major aim was to eliminate the distinction between the rich and the poor and at the same time to promote India's dignity and unity (Tarlo: 1996: 94129). After India's independence in 1947, the first president, Jawarhlal Nehru, had made clear to the Asians overseas that they should become local citizens and not wait for India to back up their interests, as it had enough problems of its own. This statement hit hard for the Asian businessmen who suffered nationalisation of their houses and businesses. The last thing they wanted was to identify with the congress leaders, dressing up in khadi. Nevertheless, women continued to wear

\footnotetext{
13 The annually published 'bleu books' on British East Africa include a rich variety of statistical material related to the import and export of various products.
} 
saris. On religious occasions, men would wear 'traditional' Indian dress. And finally, some retired businessmen nowadays like to wear khadi, to identify with the Indian traditions and the spirit of the Mahatma.

(3) During the process of cultural change, the various spiritual or religious leaders often guided the identification with India, Africa and Western Europe from above. This also included the dress habits of Asians. The most outspoken leader was the spiritual leader of the Ismailis, the Aga Khan III. In 1952, he advised his followers to regard East Africa as their permanent home. In fact, this was in line with the official policy of Nehru regarding Indians overseas. In 1954, Jawaharlal Nehru advised Indians in East Africa to cooperate with Africans, adding that they could not expect protection from the Indian government, that they were guests in the African countries. India had its own problems to solve before thinking about others.

Aga Khan III pushed his followers further than that. He advised them to replace their vernacular language of Gujerati with English as the medium of instruction at schools. Moreover, he successfully encouraged women to wear Western dress, to continue their education and to seek employment. The Ismailis were renowned for their contribution to education (for Ismailis and non-Ismailis), building hospitals and having societies which enabled Ismailis to build their own houses. 
As may be expected, not all religious leaders followed the same line and were equally successful in their interventions. The Bohra community in East Africa was liberal and openminded. Some of the most important business leaders (A.M. Jeevanjee and Yusufali Karimjee) made a strong case for a secular primary (Bohra) school in India. Initially, this school was tolerated by the Dai. However, when the liberals proposed a secular middle school as well, the Dai objected and tried to obstruct the development. He felt that a religious school was more important than a secular one. At the same time, the liberal fraction disputed the Dai's authority to use communal funds without consulting its members. In 1918, this dispute was fought out in court, where the British judge ruled that the Dai should be considered as the trustee of the funds, not their owner. The Dai responded by excommunicating his opponents. This history repeated itself in various events in which the Kenyan Bohora, A.M. Jeevanjee, played a leading role. He was succeeded by Yusufali Karimjee Jivanjee, who organized a conference in Bombay in 1944. Again, most of the organisers and participants were excommunicated (Oonk: 2009). In other words, the Ismaili as well as the Bohra elite wished their children to be educated along liberal and not along religious lines. They were open to changes in the language and dress habits, in order to adjust to the local African culture as well as that of its British rulers. In the case of the Ismalis, it was supported by their own leaders, 
whereas the Bohra community successfully used colonial law to back up their ideas. In both cases, the business community was highly influential. These businessmen were the ones who sponsored most of the projects within the community, often contributing their knowledge and experience from abroad.

\section{Changing dress habits: causes, constraints and options}

Elite traders and travellers are exposed to many different cultures and peoples from the world. The have almost unlimited access to varieties of dress, fashions and garments. They are economically independent and free to choose whatever they would like to wear, probably more than any other. At the same time, they are raised within their own culture, which created caused constraints on what to wear on what occasion. However, within the constraints, there is always a small matter of choice. Whatever the choice was, it included messages for the own community and family, but also for those beyond the direct sphere of interaction.

Within a relatively short period of time, somewhere between 1950 and 1980, an important part of the Asian-African business elite choose to dress predominantly in Western business suits. This was not a simple case of blindly accepting and following the West. On the contrary, in fact if they wanted to make their political points in official meetings or in the press, they would emphasise their 
'Indianness' by wearing ethnic attire. With this, they would stress the fact that they had a longer history in East Africa than the British did, often emphasising their moral superiority, based on Muslim, Hindu or Gandhian principles. However, with the spread of the British educational system, and to some extent its value system, the business suit including tie and shined shoes became accepted and was indeed the new conventional business dress of Asians in Africa.

This happens to coincide with two other developments. The first development was the decline in interaction with the South Asian subcontinent. During the early twentieth century, there was a decline in the Indian Ocean trade in favour of trade with Europe. The South Asian businessmen in East Africa were quick to realise that dealings with Europeans were becoming increasingly important. Initially, they were contacted by representatives of European and American firms who visited East Africa and had to be entertained. Later, a significant part of the South Asian trading elite themselves would visit Europe more often. This growing exposure to European businessmen paved the way for the acceptance of the European business suits. The decline in the trade with India, and therefore less frequent visits to the region of origin, helped to speed the departure of Asian dress habits loonk: 2004b: 70-88). Of course, this was mainly during business hours and during business gatherings, like those in the 
pictures. It would not hold true during marriages, religious occasions and informal meetings with South Asians. ${ }^{14}$

The second important development was the emergence of independent African nation-states such as Tanzania, Kenya and Uganda. This contributed to the growing confidence of Africans and the growth of 'Africanisation projects'. These projects supported the idea that Asians were no longer welcome in East Africa. The Ugandan general Idia Amin made this clear in his Asian farewell speech, in which he gave the Asian 30 days to pack up and go (on $5^{\text {th }}$ August 1972). Most Asians left the country, mainly to the United Kingdom, Canada and the United States. If we analyse the pictures of those who arrived in Europe after the Asian expulsion from East Africa, we find that most women wear saris, but most men would wear European business suits. By then, their dress habits had already changed in favour of the European business suit. In other words, they had already adopted the European business suits before they arrived in the West.

\footnotetext{
14 But this is also changing now. It seems to be accepted to turn up in 'formal suit' during marriages and religious occasions.
} 